\title{
Relationship between Green Design and Material Flow Cost Accounting in the Context of Effective Resource Utilization
}

\author{
Jui-Che Tu and Hsieh-Shan Huang * \\ Graduate School of Design, National Yunlin University of Science and Technology, Yunlin 640, Taiwan; \\ tujc@yuntech.edu.tw \\ * Correspondence: rsungo@gmail.com or r3.go@msa.hinet.net; Tel.: +886-7-721-3963; Fax: +886-7-722-1267
}

Received: 27 February 2019; Accepted: 28 March 2019; Published: 3 April 2019

\begin{abstract}
The consumption of fossil fuels has been gradually exhausting resources and deteriorating the environment on a global scale. There are two ways to resolve these problems: The application of green energy and new materials; and the development of energy efficiency techniques such as green design and material flow cost accounting. Material flow cost accounting does not create new sources of energy, but its implementation can encourage the effective use of resources or reduce the consumption of resources, and hence reduce the impact on the environment. The International Organization for Standardization has enacted material flow cost accounting as an international standard, and this will have a profound impact on multinational firms. This paper examines material flow cost accounting in the context of grounded theory, and conducts a case study on the companies which have implemented material flow cost accounting. The purpose of this research is to identify the relationship between material flow cost accounting and green design, and to provide a reference for the production design of the enterprise. After analysis, material flow cost accounting can generate detailed waste data, and provide a green design reference in actual energy conservation. These two outcomes complement each other, and will support achievement of the goal of mutual financial and environmental protection.
\end{abstract}

Keywords: ISO-14051; material flow cost accounting; green design; green accounting

\section{Introduction}

The deterioration of the global environment has led to the rise of corporate social responsibility. The increasingly forceful demands, made by much of society, that companies be responsible for their unethical practices [1]. Various improvement tools have come out. Schaltegger pointed out that the development of sustainability accounting and reporting should be orientated more towards improving management decision making [2]. One of the tools to improve management decisions is material flow cost accounting (MFCA). MFCA and green design share the same goal of environmental protection. They are both aimed towards the effective utilization of resources. For this reason, this paper sets out to explore the relationship between MFCA and green design. Job order costing and processing costing systems are the methods utilized in cost accounting to calculate the final costs of products, by adding up expenses throughout different divisions. Both methods accumulate or distribute the costs associated with defects, spoilage, and waste to the finished goods or work in process, or simply recognize such costs as expenses or losses during the period [3]. Neither method pays attention to the efficiency of resource utilization. This is why material flow cost accounting advocates the reduction of waste and resource consumption. The ISO-14051 standard declares that waste materials are the result of material losses and resource wastefulness. This paper reviews all the relevant literature 
from different countries, before and after the release of the ISO-14051, and finds that all studies support material flow cost accounting. These studies include Kokubu et al. [4] from Japan, Schmidt, and Nakajima [5] from Germany and Japan, and Christ and Burritt [6] from Australia. The MFCA Manual [7], published by the Asian Productivity Organization, the MFCA Booklet [8], published by the National Productivity Council of India, and even the Thai government [9] have all enlisted the ISO-14051 as a national standard. It is the general consensus that the implementation of material flow cost accounting will reduce the consumption of materials and energy, and the impact on the environment. It will also benefit the economy and company financial outcomes, as intended by the ISO-14051 standard, which has a focus on the balance between the input of materials or energy and the output. It is required that the materials used for production should be equal to the consumption of the products, leftovers, and waste materials. All the consumption and leftovers in each stage of production and processing are recorded in detail. The calculation of the manpower and disposal costs associated with waste disposal is made, in order to provide information to design or manufacturing personnel for future improvements. Despite the claimed functions of MFCA, this paper argues that calculation requirements alone cannot reduce resource consumption or improve resource utilization efficiency throughout production procedures. It is necessary to incorporate other methods or techniques (such as green design), and leverage the information provided by material flow cost accounting, so as to devise measures to reduce waste and spoilage. Some scholars have pointed out that the methodology is being extended, refined, and elaborated, and increasingly applied in combination with various other tools and concepts [10]. Therefore, this paper seeks to explore the context of MFCA by referring to the articles of ISO-14051, a comprehensive international standard of MFCA. The purpose of this is to examine whether the essence of this standard contains the expectations for green design, and the intention to introduce other techniques or methods to achieve energy efficiency. For the companies that have implemented MFCA to improve energy efficiency, this paper intends to explore what approaches they have adopted, and whether green design is included. Case studies are conducted on selected companies to analyze whether their improvement measures are related to green design techniques and methods. If both answers are yes, as expected by this paper, it can be concluded that MFCA and green design are complementary in promoting the effective utilization of resources.

\section{Development of MFCA}

Material flow cost accounting was first developed in the middle of the 1990s by Professor Bernd Wagner from the Institut fuer Management und Umwelt in Augsburg, Germany. It was introduced to Japan in 2000, and has been widely adopted in Japan since then. In 2008, the Japanese Industrial Standards Committee formulated a set of standards regarding material flow cost accounting for review by the International Standards Organization (ISO). The proposal was approved by the ISO Technical Committee 207, and Working Group 8 was established under the guidance of the ISO Technical Committee 207 to formulate the ISO-14051 standards. A working draft was released in March 2009, and the ISO-14051 was formally published as part of the environmental management series in November 2011 [11]. Before becoming an international standard, material flow cost accounting was known as material flow analysis, as part of green accounting in the US and Europe. The United Nations Division for Sustainable Development [12] considers green accounting as an environmental management tool to confirm and collect data regarding natural resources, material flow, and environmental improvement, as well as an analytical measurement to link environmental costs and financial information for the reference of company management and environmental decisions. The ultimate goal is to connect the management of environment planning and economic policies at the corporate level to achieve sustainability. The International Federation of Accountants [13] issued the guidelines for environmental management accounting in 2005, by defining it as the confirmation, collection, analysis, and utilization of physical information and monetary information so as to facilitate internal decisions. Physical information measures the consumption and movement of energy, water, and raw materials, and the changes and disposal of waste. Monetary information is the currency 
expression of quantified approximations of the costs and benefits, tangible and intangible, in terms of environmental improvement and resource conservation. Meanwhile, the United Nations Division for Sustainable Development refers to material flow analysis as the analysis of natural resources and physical flows. The International Federation of Accountants defines material flow analysis as the analysis of physical information. Both terms mean the analysis of material flows, as it involves the valuation and analysis of the input and output of materials throughout the production workflows, and then the comparison of costs, calculated and expressed in monetary amounts. The analysis of material flows, developed outside green accounting in Japan, added the term "costs". The result was "material flow cost accounting". Based on the articles of the ISO-14051 [14], this paper defines material flow cost accounting as the material balancing in accounting for the inputs of all the energy, water, and raw materials, and the outputs of products and waste. The International Standards Organization believes that material balancing - that is, inputs equating to outputs-ensures that all the inputs of raw materials and energy, and all the outputs of products and waste throughout the production activities, are tracked and accounted for. It is assumed that all the inputs are converted into outputs (i.e., products and waste). All the costs and expenses associated with energy and raw materials are recorded, tracked, and managed over a period of time. Material flow cost accounting is about the collation of quantitative data concerning the acquisition, transportation, internal allocation, utilization, and inventory of raw materials, the storage and shipping of finished goods, and the recycling, reusing, or disposal of waste. With a history of more than three decades, the concepts and techniques of green design can be considered relatively mature, and hence this paper does not intend to elaborate on them. That said, this paper has highlighted its philosophy in another article, as follows: (1) maximize output with a given level of input, (2) avoid pollution, (3) pursue clean production, (4) reduce impact, (5) improve environmental performance, and (6) equate input to output [15].

\section{Material and Methods}

\subsection{Method}

MFCA presumes that material flow cost accounting reduces resource consumption and environmental impact. Whilst this is a great idea, whether it is true is another issue. Its development has so far been a phenomenon, and no definite conclusions have been drawn. This paper seeks to ground the research in each element of the phenomenon, and the development of material flow cost accounting. The ISO-14051 Standard, Environmental Management-Material Flow Cost Accounting-General Framework, is a set of standardized requirements developed to track and record the costs associated with leftovers, waste, and excess materials by applying the techniques of cost accounting. Excess materials refer to the redundant elements which occur when the input materials are greater than the sum of the products, leftovers, and waste. Improvements should start from waste and excess materials. This paper grounds its research in the ISO-14051 standard, as it is becoming the guideline for material flow cost accounting, and energy efficiency and environmental protection for corporates. The purpose is to identify whether the rules contain the implicit expectations for green design in the design or manufacturing process, to reduce resource waste. To support the interpretation of ISO-14051, this paper conducts case studies on forty companies that have implemented MFCA, to understand whether green design is in use to enhance the effective utilization of resources.

Grounded theory emphasizes the development of theories by anchoring with data. It considers the induction of propositions to explain and interpret certain phenomena. Theories and prejudices cannot be developed upon any new discovery. Rather, concepts and scopes are gradually synthesized through research and analysis. The induction of theories starts from the coding process [16]. Generally speaking, grounded theory is considered the most scientific approach to qualitative studies. It is one of the more highly valued research methods social studies. Grounded theory collates data in a systematic manner, and uses the scientific approach of inferences to generalize and analyze specific circumstances. It is hoped that this bottom-up approach can establish new theories that reflect social phenomena. 
Put differently, grounded theory is not about proving a pre-developed theory. Rather, it is the synthesis of concepts and theories about a subject that is yet to be extensively researched [17]. In a nut shell, grounded theory is a quantitative method that systematically collates data and then consolidates and analyzes such data, with layers of coding from complexity to simplicity. This research methodology aims to uncover or reflect social phenomena.

Grounded theory deciphers data into three levels: open coding, axial coding, and selective coding. Open coding contextualizes the transcriptions of the raw data, and extracts the texts in each paragraph in order to form a consistent concept of the same nature or dimensions within a specific scope. Axial coding is the analysis of the open codes, by integrating the factors with the same causality and background. This allows the generalization of complex phenomena into concise and simple concepts. Selective coding retains the factors relevant to the research by predetermining a set of criteria. This process aims to induct and generalize a set of principles regarding the relationships previously questioned and intended for exploration, and then develop the central notions closer to reality. The use of selective codes to interpret events, facts, and social phenomena allows researchers to clarify their questions, and identify the relationships in relation to the subject matter.

\subsection{Research Process}

This paper uses open codes to contextualize all the relevant texts throughout the ISO-14051 articles as raw materials. This process treats each article as an analytical unit, and extracts the texts with specific meanings. If an article is short, it is completely selected in order to avoid distortions. The first column in List A1 (Appendix A) summarizes the selection results. The second step is to use axial coding on the results of the open coding in order to distill the underlying concepts, requirements, or action items. The second column in List A1 presents the findings of axial coding. Up to this point, all coding is grounded in the ISO-14051 paragraphs, without any personal interpretation by the researchers. The third stage is the application of selective coding, by deciding on the elements relevant to research topics. The issues associated with green design are incorporated by this paper in order to explore whether green design and the effective utilization of resources intended by material flow cost accounting are related, and identify the timing and occasion for green design. The third column in List A1 shows the results of selective coding. The coding process was completed via multiple meetings consisting of the author, two researchers, and the two thesis advisors.

The ground process is long and tedious, as it requires word-by-word reading and translation in order to understand the meanings and categorize the texts in terms of the actions and accountability required. This paper only provides a few examples. Please refer to List A1 (Appendix A) for the grounding results of all the ISO-14051 paragraphs.

Example 1. The first paragraph listed in the first example in List A1. ISO-14051 texts: This International Standard provides a general framework for material flow cost accounting (MFCA). Under MFCA, the flows and stocks of materials within an organization are traced and quantified in physical units (e.g., mass, volume) and the costs associated with those material flows are also evaluated. The resulting information can act as a motivator for organizations and managers "to seek opportunities to simultaneously generate financial benefits and reduce adverse environmental impacts." MFCA is applicable to any organization that uses materials and energy, regardless of their products, services, size, structure, location, and existing management and accounting systems.

This paragraph deals with the quantification of materials and the estimates of expenses incurred. It is applicable to any organization. This paper concludes that the core concept of this paragraph is to apply the techniques so that companies of any types can achieve both financial benefits and environmental protection. After going through the whole paragraph, this paper determines that the following wording can best represent the central idea, as it reiterates the reduction of the environmental impact in a way that is relevant to the responsibility of green design: "To seek opportunities to simultaneously generate financial benefits and reduce adverse environmental impacts." The above 
wording is extracted into open codes, as these texts are representative and reflective of the raw materials, and relevant to the research topics. The second step is axial coding-the identification of the key elements from the results of open coding. This stage allows various interpretations. For instance, the purpose of the ISO-14051 is to look for opportunities to improve efficiency, and this is consistent with the responsibility of green design. As the paragraph concerned is a statement for expectations, it should be treated as the mission statement of the ISO-14051 standard. This paper interprets this as a "win-win policy", as material flow cost accounting attempts to seek environmental protection and economic growth at the same time. The final stage is selective coding by grouping the results of axial coding into specific factors according to attributes. As this paper intends to analyze the overall attributes of the ISO-14051 standard, given its importance to material flow cost accounting and relevance to environmental management, the attributes identified are accounting elements, regulatory requirements, central concepts, and green design. The central concept is the appeal for the win-win. This paper decides to classify the requirement in this paragraph as the mission statement of the ISO-14051 standard.

Example 2. Example No. 18 in List A1 is Article 3.15, ISO-14051 texts: "Material flow cost accounting: tool for quantifying the flows and stocks of materials in processes or production lines in both physical and monetary units", the definition of material flow cost accounting by the ISO-14051 standard. The wording is very specific and concise. To avoid misinterpretation as a result of missing texts, this paper uses open coding to contextualize the whole paragraph. The next step is to identify the central concept for axial coding, and this paper determines it is to be the definition of material flow cost accounting. The final step is selective coding. This paper determines this paragraph deals with the system and nothing else and, hence, classifies it into system requirements.

Example 3. Example No. 55 in List A1 is about Article 6.9. The original texts are very long and come with tables to illustrate calculations. It is necessary to read through the complex texts in order to distill its central concept. The calculations and explanations accompanied with the tables in the article detail the process of costing. "... review and interpretation of the summarized data will allow the organization to identify quantity central with material losses ... be analyzed in more detail to identify the root causes of the material losses and the associated factors that incur the costs." The above wording deals with the selection for the tabulated data for further analysis so as to identify the cause for material losses. This is determined to be the central concept of the whole paragraph and, hence, extracted into open coding. The idea is to identify the reasons for a lack of efficiency in material consumption with the information revealed. This paper believes that green design should come to the fore in order to achieve improvements, once the reasons for inefficiency are identified. Hence, this paper classifies these texts with selective coding into "the factors that require the introduction of green design" in the final stage of attribute categorization.

The coded results and the core concepts of the ISO-14051 standard are summarized in List A1. The ISO-14051 standard is an accounting system of cost management, aiming to provide information and introduce green design. Its purpose is to effectively utilize resources and reduce resource wastes and environmental pollutions. This paper goes through all 57 articles of the ISO-14051 standard, and derives the following statistics regarding the relevant attributes:

(1) Mission statement: Three articles

The purpose of the standard, as an element of environmental management, is to identify the opportunities to achieve both financial benefits and environmental protection in the process of product manufacturing.

(2) Core concepts: Four articles

This is the underlying concept throughout the standards; that is, the improvement of manufacturing procedures can achieve energy efficiency and environmental protection. It is necessary to value and 
balance the inputs and outputs throughout the workflows by tracking the destination of materials. Material loss resulting from the manufacturing process should not be added onto products.

(3) Calculation methodology: Three articles

This is a mechanism for cost estimation and quantification, and is called the "quantity center" in the standards. Its purpose is to identify waste in different forms.

(4) Unit consistency: Five articles

It is reiterated throughout the standard that the unit and the currency used to quantify the materials and energy, and their changes throughout the manufacturing process, should be consistent.

(5) System requirements: 16 articles

Five articles only provide titles. Others define the framework and operational mechanisms of material flow cost accounting.

(6) Costing requirements: 13 articles

These articles define costs and sets out the procedures for cost allocations and categorization.

(7) Cost estimates: Six articles

These articles articulate the methods of calculating cumulative product costs by tallying the quantity of leftovers or inventory, wasted materials, management, and disposal costs.

(8) Green design: Seven articles

Material flow cost accounting aims to inform stakeholders that the recycling of materials indicates a lack of efficiency in production. It is necessary to identify the reasons for inefficient use of materials. Material flow cost accounting provides the relevant information and analytical techniques to pinpoint the cause for losses. One of these seven articles mentions expertise, mostly about green design knowledge and competences.

\subsection{Results}

Whether the resource waste discovered by MFCA can be improved by green design is confirmed by the implementation results released by the Ministry of Economy, Trade and Industry (METI), Japan [18], based on the achievements in energy efficiency obtained by 32 companies, which have implemented material flow cost accounting. The METI report discusses green design throughout. As summarized in Table 1, the 32 companies covered include 23 in manufacturing, five in non-manufacturing, and four chain stores with suppliers in the upper stream and manufacturers in the downstream. Technically speaking, the chain stores in the example can be classified as manufacturers. In other words, a total of 27 companies out of the 32 companies are manufacturers (only the companies numbered 24 to 28 are not in manufacturing). In fact, the ISO-14051 standard also includes five case studies from Japan, Czech, Vietnam, Germany, and the Philippines. These companies, added to Table 1 and numbered from 33 to 37, are also all in manufacturing. As the company numbered 33 and the company numbered 7 are the same Japanese company, a total of 31 companies are summarized for the METI report. The concentration of the case studies in manufacturing indicates that material flow cost accounting is more appropriate for manufacturing. 
Table 1. Measures to reduce losses in the framework of material flow cost accounting.

\begin{tabular}{|c|c|c|c|}
\hline Name of Company & Sector & Cause & Improvement \\
\hline $\begin{array}{l}\text { 1. NITTO DENKO } \\
\text { CORPORATION }\end{array}$ & Chemicals & Water of materials & Purchase of better equipment \\
\hline $\begin{array}{l}\text { 2. SEKISUI Chemical } \\
\text { Co., Ltd. }\end{array}$ & Chemicals & $\begin{array}{l}\text { Low productivity and high } \\
\text { percentage of defects }\end{array}$ & Productivity improvement and cost reduction \\
\hline 3. SUMIRON Co., Ltd. & Chemicals & $\begin{array}{l}\text { High percentages of waste } \\
\text { materials }\end{array}$ & $\begin{array}{l}\text { Manufacturing process improvement to reduce } \\
\text { material loss }\end{array}$ \\
\hline $\begin{array}{l}\text { 4. TOYO INK MFG. } \\
\text { Co., Ltd. }\end{array}$ & Chemicals & Heavy material losses & Equipment upgrade to improve processing speed \\
\hline $\begin{array}{l}\text { 5. Sumitomo Chemical } \\
\text { Co., Ltd. }\end{array}$ & Chemicals & Heavy material losses & $\begin{array}{l}\text { Production workflow improvement to reduce } \\
\text { material consumption }\end{array}$ \\
\hline $\begin{array}{l}\text { 6. Mitsubishi Tanabe } \\
\text { Pharma Corporation }\end{array}$ & Pharmaceutical & $\begin{array}{l}\text { High percentage of wastes } \\
\text { and cost of management }\end{array}$ & $\begin{array}{l}\text { Change of waste processing methods and reuse } \\
\text { of recycled materials }\end{array}$ \\
\hline 7. Canon Inc. & $\begin{array}{c}\text { Electric } \\
\text { Appliances }\end{array}$ & $\begin{array}{l}\text { Heavy consumption of } \\
\text { materials }\end{array}$ & $\begin{array}{l}\text { Change of processing and manufacturing } \\
\text { methods to reduce material consumption }\end{array}$ \\
\hline 8. Nagahama Canon Inc. & $\begin{array}{c}\text { Electric } \\
\text { Appliances }\end{array}$ & High percentage of wastes & $\begin{array}{l}\text { Employee training on the reduction of losses and } \\
\text { wastes }\end{array}$ \\
\hline 9. OMRON Corporation & $\begin{array}{c}\text { Electric } \\
\text { Appliances }\end{array}$ & $\begin{array}{l}\text { High consumption of } \\
\text { materials }\end{array}$ & $\begin{array}{l}\text { Re-molding and equipment redesign to } \\
\text { accelerate assembly speeds and reduce material } \\
\text { costs }\end{array}$ \\
\hline 10. TS Corporation & $\begin{array}{c}\text { Electric } \\
\text { Appliances }\end{array}$ & Low yields & $\begin{array}{l}\text { Improvement of production procedures to } \\
\text { produce high-value-added products }\end{array}$ \\
\hline 11. Press Manufacturer A & $\begin{array}{c}\text { Electric } \\
\text { Appliances }\end{array}$ & High percentage of wastes & $\begin{array}{l}\text { Change of product sizes and manufacturing } \\
\text { procedures }\end{array}$ \\
\hline $\begin{array}{l}\text { 12. Katagiri Seisakusho } \\
\text { Co., Ltd. }\end{array}$ & $\begin{array}{c}\text { Transportation } \\
\text { equipment }\end{array}$ & $\begin{array}{l}\text { High consumption of } \\
\text { materials }\end{array}$ & $\begin{array}{l}\text { Improvement of processing techniques and } \\
\text { productivity to reduce material costs }\end{array}$ \\
\hline $\begin{array}{l}\text { 13. GUNMA GOHKIN } \\
\text { Co., Ltd. }\end{array}$ & $\begin{array}{c}\text { Transportation } \\
\text { equipment }\end{array}$ & High consumption of energy & $\begin{array}{l}\text { New equipment and energy conservation } \\
\text { measures to reduce energy waste }\end{array}$ \\
\hline 14. Mitsuya Co., Ltd. & Metal Products & $\begin{array}{l}\text { High consumption of } \\
\text { indirect materials during } \\
\text { processing }\end{array}$ & $\begin{array}{l}\text { Use of alternative materials and change of } \\
\text { manufacturing processes to reduce the } \\
\text { consumption of water and materials }\end{array}$ \\
\hline $\begin{array}{l}\text { 15. KOSEI Aluminum } \\
\text { Co., Ltd. }\end{array}$ & Metal Products & $\begin{array}{l}\text { High percentage of materials } \\
\text { that require recycling }\end{array}$ & $\begin{array}{l}\text { Improvement of manufacturing technologies to } \\
\text { reduce the requirement for material recycling }\end{array}$ \\
\hline $\begin{array}{l}\text { 16. MIWA LOCK Co., } \\
\text { Ltd. }\end{array}$ & Metal Products & $\begin{array}{l}\text { High consumption of } \\
\text { materials }\end{array}$ & Re-molding to reduce material consumption \\
\hline $\begin{array}{l}\text { 17. NIPPON FILCON } \\
\text { Co., Ltd. }\end{array}$ & Metal Products & $\begin{array}{l}\text { High consumption of } \\
\text { materials }\end{array}$ & $\begin{array}{l}\text { Improvement of procedural control to avoid } \\
\text { material consumption whilst the machine is } \\
\text { idling or out of order }\end{array}$ \\
\hline 18. Shimizu Printing Inc. & Pulp and Paper & $\begin{array}{l}\text { High consumption of } \\
\text { materials and manpower }\end{array}$ & $\begin{array}{l}\text { Adjustment of printing procedures to save ink } \\
\text { and manpower, based on the suggestion from } \\
\text { onsite workers }\end{array}$ \\
\hline $\begin{array}{l}\text { 19. THE REBIRTH Co., } \\
\text { Ltd. }\end{array}$ & Pulp and Paper & $\begin{array}{l}\text { Heavy consumption of } \\
\text { materials and energy }\end{array}$ & $\begin{array}{l}\text { Improvement of production procedures and the } \\
\text { reused of recycled leftovers to reduce the } \\
\text { consumption of materials and energy }\end{array}$ \\
\hline 20. GUNZE Limited & $\begin{array}{l}\text { Textiles and } \\
\text { Apparels }\end{array}$ & High defect rates & Redesign and new materials to increase yields \\
\hline $\begin{array}{l}\text { 21. Kohshin Rubber Co., } \\
\text { Ltd. }\end{array}$ & $\begin{array}{l}\text { Rubber } \\
\text { Products }\end{array}$ & Too much leftover material & $\begin{array}{l}\text { Material reuse during the manufacturing process } \\
\text { to reduce material waste }\end{array}$ \\
\hline 22. Shinryo Co., Ltd. & Foods & Defects due to human errors & $\begin{array}{l}\text { Operational improvement to increase } \\
\text { productivity, materials recycling, and nightshift } \\
\text { reduction }\end{array}$ \\
\hline $\begin{array}{l}\text { 23. KODAI SANGYO } \\
\text { Co., Ltd. }\end{array}$ & Other Products & High defect rates & $\begin{array}{l}\text { Resetting of procurement standards to reduce } \\
\text { defects }\end{array}$ \\
\hline 24. JFE group & Construction & $\begin{array}{l}\text { Decisions over } \\
\text { sub-contracting }\end{array}$ & $\begin{array}{l}\text { Evaluations of different engineering techniques } \\
\text { by using the information provided by material } \\
\text { flow cost accounting }\end{array}$ \\
\hline 25. GUNZE Limited & $\begin{array}{l}\text { Textiles and } \\
\text { Apparels }\end{array}$ & $\begin{array}{l}\text { Low product turnovers and } \\
\text { high returns }\end{array}$ & $\begin{array}{l}\text { Strategies developed on the basis of material flow } \\
\text { cost accounting to reduce losses in the process }\end{array}$ \\
\hline 26. OHMI BUSSAN, Inc. & Other Services & $\begin{array}{l}\text { Inventory and warehousing } \\
\text { expenses }\end{array}$ & $\begin{array}{l}\text { Inventory reduction and productivity } \\
\text { improvement by using material flow cost } \\
\text { accounting as a management tool }\end{array}$ \\
\hline
\end{tabular}


Table 1. Cont

\begin{tabular}{|c|c|c|c|}
\hline Name of Company & Sector & Cause & Improvement \\
\hline 27. Sanden Corporation & Machinery & $\begin{array}{l}\text { Equipment deployment } \\
\text { costs too high, due to a large } \\
\text { number of service outlets }\end{array}$ & $\begin{array}{l}\text { Deployment of shareable equipment for repeated } \\
\text { use according to the calculation with material } \\
\text { flow cost accounting }\end{array}$ \\
\hline 28. Convenience store A & Retail Trade & Too much expired food & $\begin{array}{l}\text { Precise ordering to reduce waste food and carbon } \\
\text { emissions based on the analysis of material flow } \\
\text { cost accounting }\end{array}$ \\
\hline $\begin{array}{l}\text { 30. Panasonic Ecology } \\
\text { Systems Co., Ltd. } \\
\text { SC team }\end{array}$ & $\begin{array}{l}\text { Electric } \\
\text { Appliances } \\
\text { Chemicals }\end{array}$ & Too much waste material & $\begin{array}{l}\text { Analysis of the whole supply chain to balance } \\
\text { the outputs from upper stream to the inputs for } \\
\text { downstream }\end{array}$ \\
\hline $\begin{array}{l}\text { 32. Ohu Wood Works } \\
\text { Co., Ltd. SC team }\end{array}$ & Metal Products & $\begin{array}{l}\text { High material consumption } \\
\text { and low yields }\end{array}$ & $\begin{array}{l}\text { Formulating of shared requirements to } \\
\text { standardize material requirements, reduce } \\
\text { material consumption, and enhance yields }\end{array}$ \\
\hline 33. The same with 7 & $\begin{array}{c}\text { Electric } \\
\text { Appliances }\end{array}$ & $\begin{array}{l}\text { High consumption of } \\
\text { materials }\end{array}$ & $\begin{array}{l}\text { Change of processing procedures to reduce } \\
\text { material consumption }\end{array}$ \\
\hline $\begin{array}{l}\text { 34. A small company in } \\
\text { the Czech }\end{array}$ & $\begin{array}{l}\text { Manufacturing } \\
\text { Factory }\end{array}$ & $\begin{array}{l}\text { Too much waste materials } \\
\text { and too high disposal } \\
\text { expenses }\end{array}$ & $\begin{array}{l}\text { Improvement of material utilization efficiency by } \\
\text { using the analysis of material flow cost } \\
\text { accounting as a tool }\end{array}$ \\
\hline $\begin{array}{l}\text { 35. A Vietnamese coffee } \\
\text { manufacturing factory }\end{array}$ & $\begin{array}{l}\text { Agricultural } \\
\text { Manufacturing }\end{array}$ & $\begin{array}{l}\text { Overuse of fertilizers and } \\
\text { materials }\end{array}$ & $\begin{array}{l}\text { Advocate for green coffee beans by initiating } \\
\text { training programs to reduce material } \\
\text { consumption and environmental impacts }\end{array}$ \\
\hline
\end{tabular}

\section{Analysis and Discussion}

This paper derives the following percentages (Figure 1) based on the statistics shown in List A1 (Appendix A).

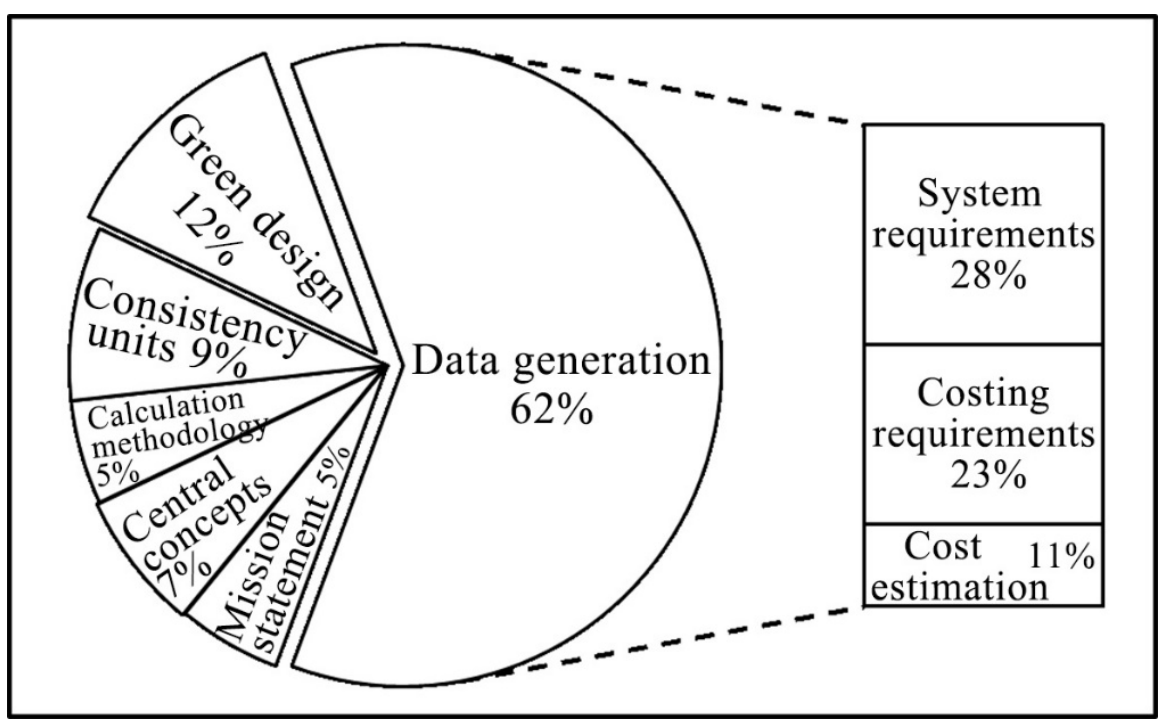

Figure 1. Percentage of ISO-14051 attributes. 
(1) Data generation:

Most of the relevant articles outline the methods for the estimation and calculation of the change in materials throughout the production process. A total of 35 articles deal with system requirements, costing requirements, and cost estimates; that is, $62 \%$ of the articles are about data generation.

(2) Waste confirmation:

The greatest function of this standard is to pinpoint where, the volume, and the amount of waste. About $34 \%$ of the articles on data generation are on the costing rule and cost calculation, to track the usage cost for materials or energy. Any costs not able to be categorized, or the gap between final inputs and output, are defined as waste. The idea is to spot where the waste is in a timely manner.

(3) Mentioning of green design:

The core element, objectives, and green design of waste improvements emphasize the betterment of manufacturing processes for environmental protection and energy efficiency. How the improvements should be made is up to stakeholders-the green design personnel or engineering staff. The purpose of this standard can only be achieved with hands-on improvements by engineers. This accounts for $24 \%$ of the total.

(4) Other requirements:

Other requirements refer to the consistency in units for cost calculations, and the definition of calculation mechanisms. This is less relevant to this paper. Eight articles consider this, or $14 \%$ of the total.

In sum, there are no straightforward rules on energy efficiency technology in ISO-14051. Whilst the information provided by MFCA is a sufficient basis for improvement, support from engineering and technical knowhow are required to achieve energy efficiency and environmental protection. This is evidenced by $24 \%$ of the articles being dedicated to core elements, objectives, and green design, and the pursuit of manufacturing process improvement to achieve environmental protection and energy efficiency. Studies have shown that after obtaining information, it should be administered to plant personnel for hotspot improvements [19]. Same as the analysis of this study. Below is an analysis of the information presented in Table 1. The causes for waste shown in Table 1 are the analytical findings on the basis of material flow cost accounting. The majority of waste is related to materials and energy, in addition to manpower inefficiency, defects, leftovers, and inventory. These are all calculations made with cost accounting techniques. The quantity in central, according to the physical quantities of opening inputs and closing inventories. Whilst the information is provided with material flow cost accounting, the improvement relates to green design techniques and methods. The National Productivity Council, India (2015), in its manual to introduce material flow cost accounting, also uses four manufacturers as examples and green design as the solutions. The report indicates that Japan Productivity sent experts to India to assist with the promotion of material flow cost accounting from June 2012 to March 2014. Four companies were involved in the process: Sainest Tubes Pvt. Ltd. (a manufacturer of carbon steel seamless pipes, Gandhinagar, India), Bhagwati Spherocast (a manufacturer of high duty grey iron and ductile iron castings, Ahmedabad, India), Somany Ceramics (Kadi, India), and Baroda Moulds and Dies (Waghodia, India). The report released by the National Productivity Council describes the issues identified by material flow cost accounting that require improvement. These include material and energy waste, defects, and low productivity. All the details on energy efficiency and material values are available on the official website of the National Productivity Council, India. This paper focuses on the introduction of green energy, in the pursuit of tidiness, cleanness, and precision, to improve productivity with green design, and by upgrading equipment and training employees. The following is a list of the green design techniques and methods from the above literature: 
(1) Equipment upgrade: New equipment, re-molding, and equipment redesign;

(2) Design changes: Redesign of products, production flows, and manufacturing methods;

(3) Competence improvement: Employee training in equipment operations so as to reduce waste;

(4) Recycling and reuse: Reuse of waste and recycled leftovers;

(5) Material replacements: Use of alternative materials and development of new materials to reduce energy consumption;

(6) Standard resetting: Renewal of the standards for procurements.

The summary suggests that the 31 companies in the case study, and the four manufacturers in India that have implemented MFCA to resolve waste problems, have all adopted green design techniques and methods. Based on the above findings, this paper believes that both the information provided by material flow cost accounting and the introduction of green design are required to facilitate the effective utilization of corporate resources. This will be a daunting challenge for engineering personnel, because the reduction of waste ultimately depends on the performance of onsite engineers. The data collated via material flow cost accounting and the assessment of such data during the manufacturing process can shed light on the causes of resource waste. It will then be necessary to apply green design and technology to maximize outputs with a given level of inputs. With effective use of resources and reduction of the environmental impact, it will be possible to create a win-win for economic growth and environmental protection.

\section{Conclusions}

The analysis indicates that $62 \%$ of the articles in ISO-14051 are about data generation. It can be hence inferred that MFCA focuses on cost calculations and records. The requirements for improvement technologies or methods are yet to be formulated. This is consistent with the concern raised by this paper: MFCA should be combined with other knowledge and skillsets to achieve materials or energy savings. This paper concludes that the general approach to achieve energy efficiency and environmental protection is to combine green design with material flow cost accounting.

(1) Data generation by material flow cost accounting:

Process costing and job costing in cost accounting calculate the cumulative expenses through different divisions, and derive the final cost for products. However, they ignore the balancing of inputs and outputs of materials or energy. On the contrary, MFCA emphasizes that inputs should equate to outputs. Namely, the materials used for production should equate to usage plus leftover materials, waste materials, and wasted materials. Waste materials and wasted materials are considered a loss of materials, and hence a waste of resources. It is; therefore, necessary to document, in detail, the usage and leftovers for each stage, and estimate the required costs for labor, materials, and energy associated with waste. This information is provided to design or manufacturing personnel as the basis for improvement, so that production staff will seek to reduce leftovers and waste. This is the largest contribution of MCFA to the effective use of resources.

(2) Engineering and technical support required for energy efficiency:

The overall concept and the actual implementation of MFCA capture the tracking of materials and energy used by all production activities. The attention to detail is such that it detects the small variance between inputs and outputs, and ultimately identifies where the waste occurs. Strictly speaking, this is to generate information for internal management. Therefore, it is still necessary to combine domain knowledge and competences, such as technology updates, equipment replacement, and energy efficient material development, to reduce or avoid waste. This ensures environmental protection via energy/material efficiency. 
(3) Complementary to green design:

According to Table 1, all the improvement measures start with the calculation of the material costs and subsequent waste on the production lines. This is followed with creative ideas, such as the use of energy efficient materials to reduce waste and lower disposal costs. Other solutions include the redesign of the products and manufacturing processes to avoid waste. The contribution of material flow cost accounting is the information it provides, by evaluating and converting resource loss into monetary values. Engineers then refer to the data collected by material flow cost accounting and devise measures to identify the hidden waste of resources, and apply green design expertise and competences to seek improvement. The creation of a win-win situation for economic growth and environmental protection requires the maximization of outputs with a given level of resources, the reduction of waste and energy consumption, and the switch from waste processing to pollution prevention. In sum, product design should be environmentally friendly from the outset.

(4) For future research:

This study is a preliminary discussion of MFCA and green design. It was found that the two have complementary relationships in effective resource utilization, but no detailed cost-benefit analysis has been revealed. It is harder to convince companies to use green design to improve the material waste found by MFCA. Future research should be directed toward cost analysis of the green design intervention before and after improvement. It is possible to establish actual relevant data for both in increasing the effective use of resources.

Author Contributions: In this article, research was done by H.-S.H. under the guidance of J.-C.T.; J.-C.T. provided the theme direction, and the researcher then collected and analyzed the data. H.-S.H. and J.-C.T. have read and approved the final manuscript.

Funding: This research received no external funding.

Conflicts of Interest: The authors declare no conflict of interest.

\section{Appendix A}

Table A1. Grounded coding on ISO-14051 material flow cost accounting.

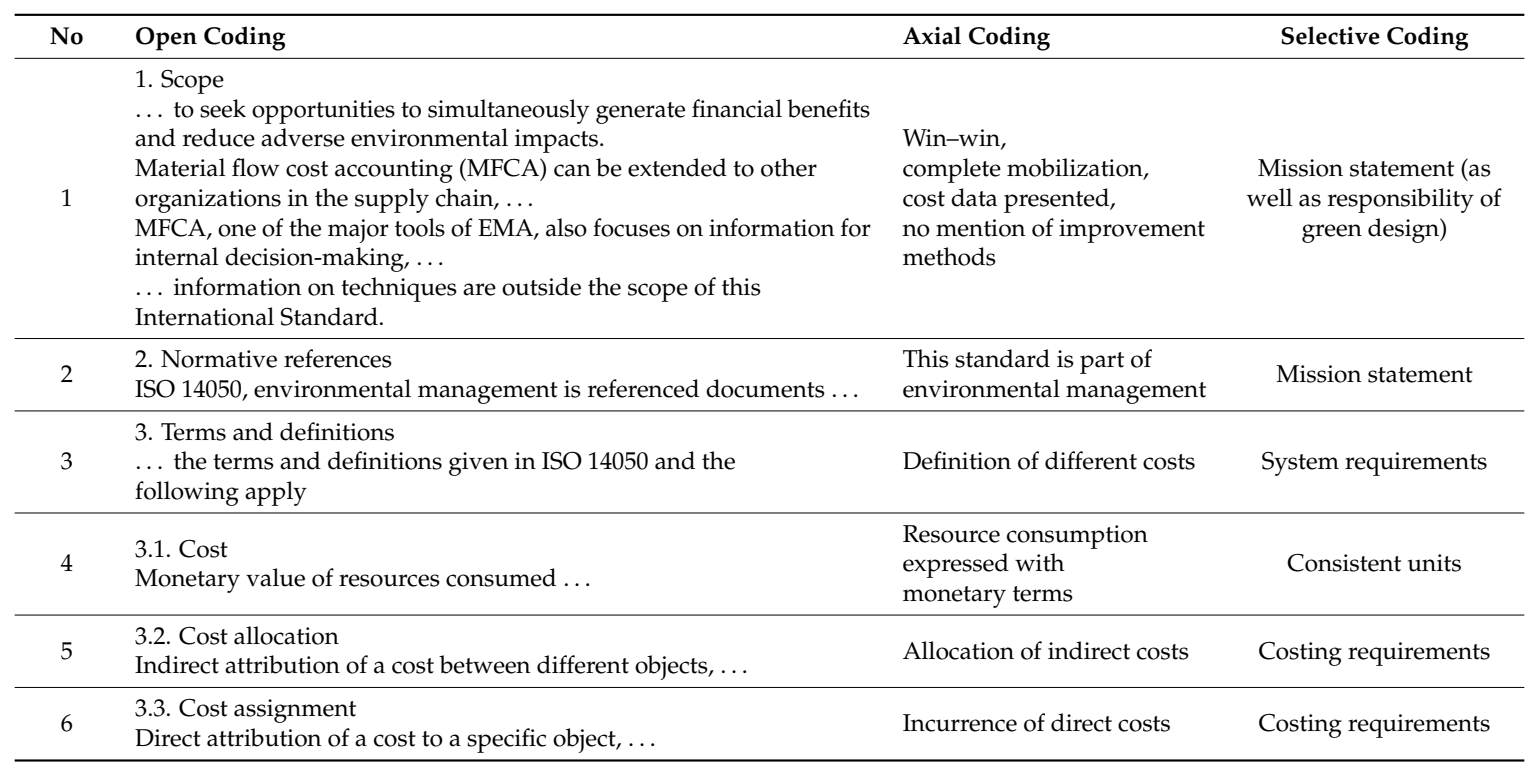


Table A1. Cont.

\begin{tabular}{|c|c|c|c|}
\hline No & Open Coding & Axial Coding & Selective Coding \\
\hline 7 & $\begin{array}{l}\text { 3.4. Energy cost } \\
\text {... electricity, fuels, steam, heat, compressed air, and other like media. }\end{array}$ & Itemization of energy cost & System requirements \\
\hline 9 & $\begin{array}{l}\text { 3.6. Energy use } \\
\text { Manner or kind of application of energy ... }\end{array}$ & $\begin{array}{l}\text { Examples of different types } \\
\text { of energy }\end{array}$ & System requirements \\
\hline 11 & $\begin{array}{l}\text { 3.8. Input } \\
\text { Material or energy flow that enters a quantity center. }\end{array}$ & Definition of material inputs & System requirements \\
\hline 12 & $\begin{array}{l}\text { 3.9. Inventory } \\
\text { Stock of materials, intermediate products, products in process, } \\
\text { finished products. }\end{array}$ & $\begin{array}{l}\text { Definition of inventory } \\
\text { materials and finished goods }\end{array}$ & System requirements \\
\hline 14 & $\begin{array}{l}\text { 3.11. Material balance } \\
\text { Comparison of physical quantities of inputs, outputs, and inventory } \\
\text { changes... }\end{array}$ & $\begin{array}{l}\text { Estimates and comparisons } \\
\text { of inputs and outputs }\end{array}$ & Cost estimates \\
\hline 15 & $\begin{array}{l}\text { 3.12. Material cost } \\
\text { Cost for a substance that enters and/or leaves a quantity center. } \\
\text { Material cost can be calculated in various ways, ... }\end{array}$ & $\begin{array}{l}\text { Any materials entering the } \\
\text { quantity center counted } \\
\text { as costs; } \\
\text { choice over costing systems }\end{array}$ & Costing requirements \\
\hline 16 & $\begin{array}{l}\text { 3.13. Material distribution percentage } \\
\text { Proportion of the material inputs that flow into products or } \\
\text { material losses. }\end{array}$ & $\begin{array}{l}\text { Calculation and allocation of } \\
\text { material costs }\end{array}$ & Cost estimates \\
\hline 20 & $\begin{array}{l}\text { 3.17. Output } \\
\text { Product, material loss, or energy loss that leaves a quantity center. }\end{array}$ & Spoilage as an output & Costing requirements \\
\hline 21 & $\begin{array}{l}\text { 3.18. Process } \\
\text { Set of interrelated or interacting activities that transforms inputs } \\
\text { to outputs. }\end{array}$ & $\begin{array}{l}\text { Manufacturing procedures } \\
\text { (underlying the regulations) }\end{array}$ & Mission statement \\
\hline 22 & $\begin{array}{l}\text { 3.19. Product } \\
\text { Any goods or service. }\end{array}$ & Definition of finished goods & Costing requirements \\
\hline 23 & $\begin{array}{l}\text { 3.20. Quantity center } \\
\ldots \text { which inputs and outputs are quantified in physical and } \\
\text { monetary units. }\end{array}$ & $\begin{array}{l}\text { Calculation of quantities and } \\
\text { values (establishment of a } \\
\text { quantity center) }\end{array}$ & $\begin{array}{l}\text { Calculation } \\
\text { methodology }\end{array}$ \\
\hline 24 & $\begin{array}{l}\text { 3.21. System cost } \\
\text { Cost incurred in the course of in-house handling of the material flows, } \\
\ldots\end{array}$ & $\begin{array}{l}\text { Costs incurred by } \\
\text { manufacturing procedures }\end{array}$ & Costing requirements \\
\hline 25 & $\begin{array}{l}\text { 3.22. Waste management cost } \\
\text { Cost of handling material losses generated in a quantity center. }\end{array}$ & Expenses for waste disposal & Costing requirements \\
\hline 26 & 4. Objective and principles of MFCA & $\begin{array}{l}\text { Purpose of material flow } \\
\text { cost accounting }\end{array}$ & Title \\
\hline 27 & $\begin{array}{l}\text { 4.1. Objective } \\
\ldots \text { enhance both environmental and financial performance through } \\
\text { improved material and energy use... }\end{array}$ & $\begin{array}{l}\text { Manufacturing procedure } \\
\text { improvement for energy } \\
\text { efficiency and environmental } \\
\text { protection (same purpose as } \\
\text { green design) }\end{array}$ & Core concept \\
\hline
\end{tabular}


Table A1. Cont.

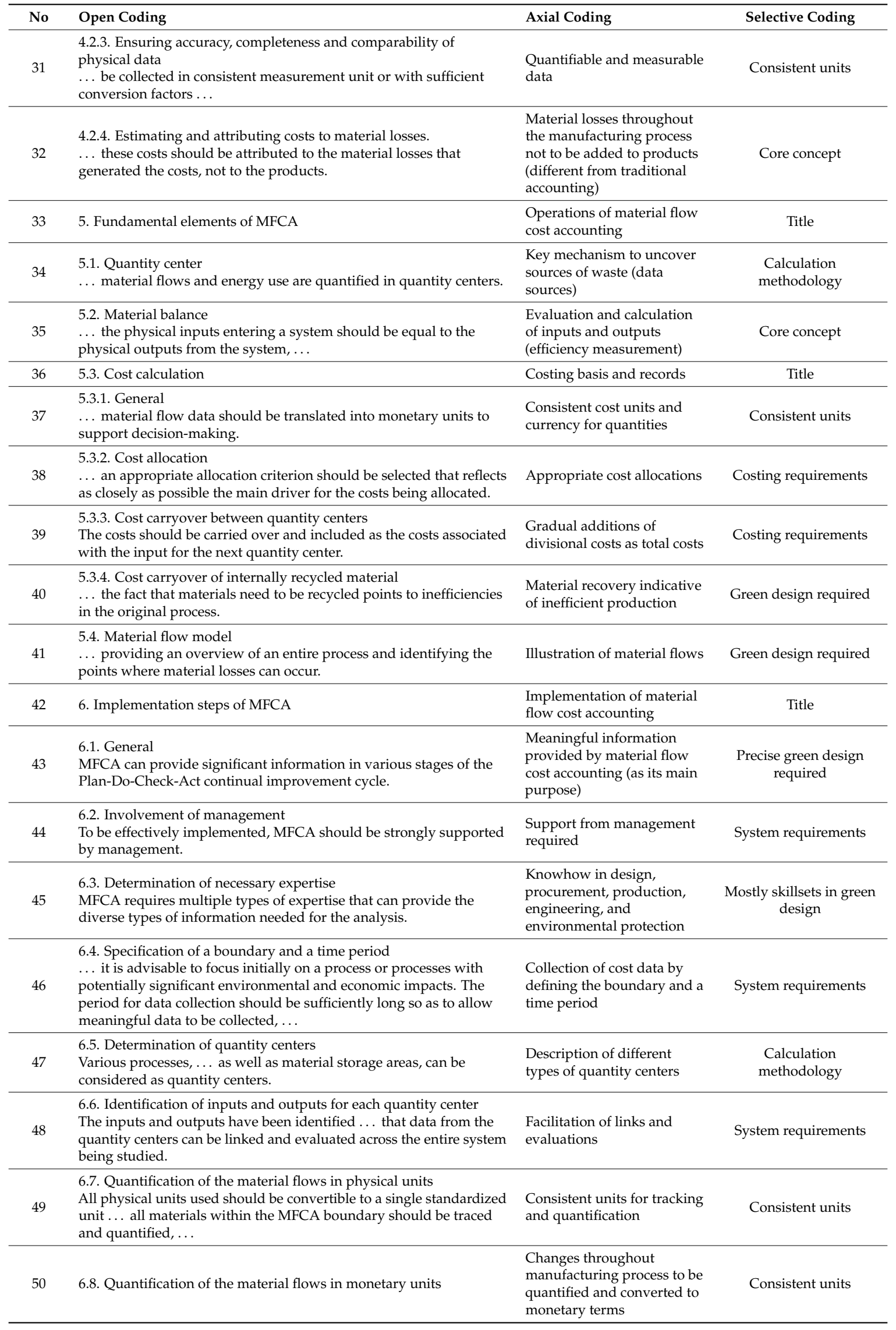


Table A1. Cont.

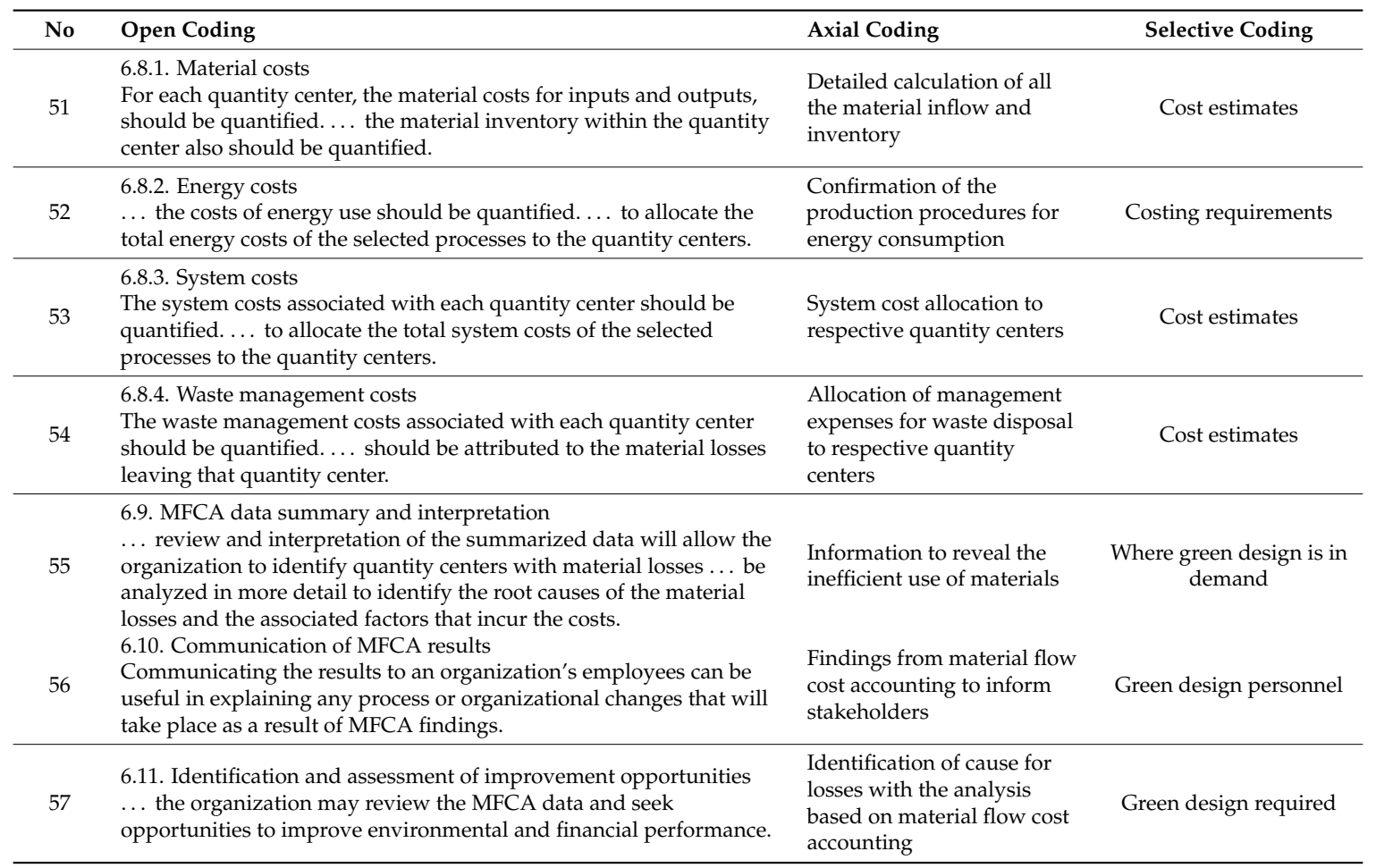

Source: Compiled by this study.

\section{References}

1. Gallardo-Vázquez, D.; Barroso-Méndez, M.J.; Pajuelo-Moreno, M.L.; Sánchez-Meca, J. Corporate Social Responsibility Disclosure and Performance: A Meta-Analytic Approach. Sustainability 2019, 11, 1115. [CrossRef]

2. Burritt, R.L.; Schaltegger, S. Sustainability accounting and reporting: Fad or trend? Account. Audit. Account. J. 2010, 23, 829-846. [CrossRef]

3. Horngren, C.T. Cost Accounting: A Managerial Emphasis, 14th ed.; Pearson Education: Upper Saddle River, NJ, USA, 2014; pp. 706-721.

4. Kokubu, K.; Campos, M.K.S.; Furukawa, Y.; Tachikawa, H. Material Flow Cost Accounting with ISO 14051. In ISO Management Systems; January-February; ISO Central Secretariat: Geneva, Switzerland, 2009; Volume 9, pp. 15-18. Available online: http:/ / docshare01.docshare.tips/files/15239/152399158.pdf (accessed on 22 February 2019).

5. Schmidt, M.; Nakajima, M. Material flow cost accounting as an approach to improve resource efficiency in manufacturing companies. Resources 2013, 2, 358-369. [CrossRef]

6. Christ, K.L.; Burritt, R.L. ISO 14051: A new era for MFCA implementation and research. Rev. Contab. Span. Account. Rev. 2016, 19, 1-9. [CrossRef]

7. Asian Productivity Organization. Manual on Material Flow Cost Accounting: ISO 14051; Hirakawa Kogyosha Co., Ltd.: Tokyo, Japan, 2014; Available online: http:/ / www.apo-tokyo.org/publications / wpcontent/uploads/sites/5/Manual_on_Material_Flow_Cost_Accounting_ISO14051-2014.pdf (accessed on 18 February 2019).

8. National Productivity Council of India. Booklet on Material Flow Cost Accounting. 2015. Available online: http:/ / www.npcindia.gov.in/wp-content/uploads/2015/02/MFCA-NPC-BOOKLET.pdf (accessed on 18 February 2019).

9. The Ministry of Industry. Draft for Industrial Product Standards: Framework for Material Flow Cost Accounting. In Royal Thai Government Gazette; Ministry of Industry: Bangkok, Thailand, 24 December 2013; Volume 130, p. 11. 
10. Guenther, E.; Jasch, C.; Schmidt, M.; Wagner, B.; Ilg, P. Material Flow Cost Accounting_Looking back and ahead. J. Clean. Prod. 2015, 108, 1249-1254. [CrossRef]

11. Lu, K.L.; Li, Y.M. Formulation Principles and Implementation Benefits of "ISO 14045 Eco-efficiency" and "ISO 14051 Material Flow Cost Accounting". In Sustainable Industrial Development Quarterly; Industrial Development Bureau: Taipei, Taiwan, 2012; Volume 61, pp. 46-54. Available online: http://catalog. digitalarchives.tw/item/00/5e/e4/6f.html (accessed on 22 February 2019).

12. United Nations. Environmental Management Accounting: Procedures and Principles; Technical Report; UN Division for Sustainable Development: New York, NY, USA, 2001; Available online: https: //sustainabledevelopment.un.org/content/documents/proceduresandprinciples.pdf (accessed on 18 February 2019).

13. International Federation of Accountants Website. Available online: http://www.ifac.org/ (accessed on 18 February 2019).

14. ISO14051. Environmental Management-Material Flow Cost Accounting-General Framework; International Organization for Standardization: Geneva, Switzerland, 2011; Available online: http://www.iso.org/ iso / catalogue_detail.htm?csnumber=50986 (accessed on 18 February 2019).

15. Tu, J.C.; Huang, H.S. Analysis on the Relationship between Green Accounting and Green Design for Enterprises. Sustainability 2015, 7, 6264-6277. [CrossRef]

16. Lee, P.L. Grounded theory. In Methods of Design Research; Guan, S.S., Ed.; Chuan Hwa Book: Taipei, Taiwan, 2010; pp. 290-293.

17. Hu, Y.H. Qualitative Studies-Theories, Methodologies and Female Gender Studies in Taiwan, 2nd ed.; Liwen Publishing Group: Taipei, Taiwan, 2008; p. 47.

18. Ministry of Economy, Trade and Industry, Japan. Material Flow Cost Accounting MFCA Case Examples 2011. In Material Flow Cost Accounting Introduction, Case Studies in Japan and Implementation Results; Appendix 1; Ministry of Economy, Trade and Industry: Tokyo, Japan, 2011; p. 4. Available online: http:/ / www.meti.go. jp/meti_lib/report/2011fy/E001446.pdf (accessed on 22 February 2019).

19. Huang, S.Y.; Chiu, A.A.; Chao, P.C.; Wang, N. The Application of Material Flow Cost Accounting in Waste Reduction. Sustainability 2019, 11, 1270. [CrossRef]

(C) 2019 by the authors. Licensee MDPI, Basel, Switzerland. This article is an open access article distributed under the terms and conditions of the Creative Commons Attribution (CC BY) license (http://creativecommons.org/licenses/by/4.0/). 